\title{
Factors associated with home deliveries in Thampalakamam, Trincomalee
}

\author{
P Lukumar ${ }^{1}$ and A Pathmeswaran ${ }^{2}$ \\ (Index words: Deficiencies in delivery of antenatal care, poor education of women)
}

\begin{abstract}
Introduction In Sri Lanka, more than $95 \%$ of women deliver in hospital. There is regional variation in the rate of home deliveries, and in some areas a significant number of mothers deliver at home.

Objective The objective of the present study was to identify the factors associated with home deliveries in Thampalakamam, Trincomalee.

Methodology Ours was a community based, exploratory type of case control study. Cases were home deliveries during the period from Jan 1, 2000 to Dec 31, 2002 in Thampalakamam Divisonal Director of Health Services (DDHS) area. Controls were institutional deliveries among women residing in Thampalakamam DDHS area during the same period. A total of 139 cases and 278 controls were identified for this study. Data was collected at the household level using an interviewer-administered questionnaire.

Results The following factors were found to have strong association with home deliveries: being a Muslim (OR $=33.0,95 \% \mathrm{Cl} 16.8-64.8)$, low (<grade 5) maternal education $(\mathrm{OR}=3.5,95 \% \mathrm{Cl} 1.8-6.6)$, parity more than 3 $(\mathrm{OR}=3.2,95 \% \mathrm{Cl} 1.5-6.6)$ not being visited by a public health midwife $(\mathrm{OR}=2.4,95 \% \mathrm{Cl} 0.8-6.9)$, not being seen by a medical officer during the antenatal period (OR=7.0, 95\% Cl 0.6-83.3). Lack of transport (35.5\%) was mentioned as main reason for home deliveries by the women. Of the home deliveries 95\% were assisted by a traditional birth attendant.
\end{abstract}

Conclusions Poor education of women and deficiencies in the delivery of antenatal care were found to be important risk factors for home deliveries.

\section{Introduction}

Home deliveries are associated with increased risk of maternal and perinatal morbidity and mortality [1]. In Sri Lanka over $95 \%$ of the births take place in hospitals, but this is not uniform throughout the country [2]. There is regional variation in the proportion of home deliveries. The proportion of home deliveries is higher than the national figure in Thampalakamam in the Trincomalee District [3].

There are several reasons why deliveries happen at home, whether planned or not. Factors such as educational level, income, family type, culture and religion, social taboos, previous pregnancy outcome, and the influence of traditional birth attendants come into play in decision making regarding place of delivery [4].

In Sri Lanka, a majority of the population live in rural areas. The availability of and access to public services such as transport, education, and health services are lower in these when compared to urban areas. Some of the villages have poor roads and transport facilities. Public transport is limited to certain areas and certain hours of the day. Few people can afford private transport. This leads to delay in reaching the hospital in an emergency. For these and similar reasons people tend to seek traditional or alternative medical services which are available within their neighbourhood community [5].

\section{Methodology}

\section{Study area}

This study was done in Thampalakamam (DDHS) area. Thampalakamam is situated in the western part of Trincomalee District in Sri Lanka. A majority of the population are Muslims (52.5\%), followed by Sinhalese and Tamils $(25.3 \%$ and $22.2 \%)$. This area is affected by the hostilities pertaining to the region, principally between the government forces and the forces of the LTTE rebels.

Within the Thampalakamam DDHS area there is a peripheral unit and a central dispensary. Most people in this area also use the Trincomalee General Hospital and Kantale Base Hospital. Thampalakamam health unit is divided into 12 Public Health Midwife areas. Of these 12 areas, six were vacant during the study period. There was no DDHS during the year 2000. A DDHS was appointed in Aug 2001 and he remained in position during the rest of the study period.

\section{Study design}

This study was an exploratory type of case control study.

\section{Study population}

The study population included the women who had delivered between Jan 1, 2000 and Dec 31, 2002 from Thampalakamam DDHS area. Only registered live births were included in the study population.

\footnotetext{
${ }^{1}$ Medical Officer of Health, Horowpothana and ${ }^{2}$ Department of Community Medicine, Faculty of Medicine, University of Kelaniya, Sri Lanka.

Correspondence: PL, Department of Community Medicine, Faculty of Medicine, University of Jaffna, Sri Lanka. e-mail: <lukumar@hotmail.com> (Competing interests: none declared). Received 15 September 2005 and revised version accepted 30 December 2005.
} 


\section{Selection of cases}

Cases were identified from the birth registry maintained at the Divisional Secretary's Office, Thampalakamam. This was done in two stages.

1. From the birth registry all births during the study period were identified.

2. From these identified births, all births with the place of delivery mentioned as a household address were selected as cases.

\section{Selection of controls}

Controls were selected from the birth and immunization register maintained by the Public Health Midwives (PHMM) of the Thampalakamam area. All the hospital deliveries of women residing in Thampalakamam DDHS area during the study period were listed from this register. From this list controls were selected by simple random sampling using random number tables.

\section{Sample size determination}

We wanted to identify factors that doubled the risk of home deliveries and had 50\% prevalence in the community. Sample size was determined using Epi Info version 6 . With $95 \%$ confidence and power of $80 \%$, the calculated minimum sample size was 111 cases and 222 controls.

\section{Study instrument}

A specially designed interviewer administered structured questionnaire was used as the study instrument. This questionnaire was initially prepared in the English language and translated into Tamil and Sinhala.

\section{Selection and training of interviewers}

Three women health volunteers who had worked with non-governmental organisations in the area were selected as interviewers. Two of the interviewers were Tamil, and the other was a Sinhalese and their mean age was 22 years. The interviewers were trained by one of the authors (PL).

\section{Data collection}

Data were collected by interviewing the women in their homes.

\section{Data analysis}

Data were analysed using SPSS version 10.01. Crude and adjusted odds ratios were calculated using binary logistic regression analysis. Approval for this study was obtained from Ethics Committee, Faculty of Medicine, University of Kelaniya.

\section{Results}

Home deliveries were $7 \%$ of the total registered births in Thampalakamam DDHS area during the study period. There were 139 cases and 260 controls included in the study.

\section{Socio-economic factors}

Among the home deliveries, 120 (86.4\%) women were Muslims (Table 1). Muslims when compared to other

Table 1. Distribution of predictor variables among cases and controls

\begin{tabular}{|c|c|c|c|c|}
\hline \multirow{3}{*}{$\begin{array}{l}\text { Variable } \\
\text { Ethnicity }\end{array}$} & \multirow{2}{*}{\multicolumn{2}{|c|}{$\frac{\text { Cases }(n=139)}{\text { Number }(\%)}$}} & \multirow{2}{*}{\multicolumn{2}{|c|}{$\frac{\text { Controls }(n=260)}{\text { Number }(\%)}$}} \\
\hline & & & & \\
\hline & & & & \\
\hline Muslim & 120 & 86.4 & 39 & 15 \\
\hline Tamil & 19 & 13.6 & 124 & 47.7 \\
\hline Sinhalese & 0 & 0 & 97 & 37.3 \\
\hline Mother's age & & & & \\
\hline$\geq 35$ years & 30 & 21.6 & 22 & 8.5 \\
\hline$<35$ years & 109 & 78.4 & 238 & 91.5 \\
\hline Mother's educa & & & & \\
\hline$<5$ years & 84 & 60.4 & 101 & 38.8 \\
\hline$\geq 5$ years & 55 & 39.6 & 159 & 61.2 \\
\hline Parity & & & & \\
\hline $1-3$ & 76 & 54.7 & 225 & 86.5 \\
\hline$>3$ & 63 & 45.3 & 35 & 13.5 \\
\hline $\begin{array}{l}\text { Per capita mont } \\
\text { income }\end{array}$ & & & & \\
\hline$<500 \mathrm{Rs}$ & 114 & 82.0 & 141 & 54.2 \\
\hline$\geq 500 \mathrm{Rs}$ & 25 & 18.0 & 119 & 45.8 \\
\hline $\begin{array}{l}\text { Ownership of th } \\
\text { house }\end{array}$ & & & & \\
\hline Own house & 128 & 92.1 & 232 & 89.2 \\
\hline Rented house & 11 & 7.9 & 28 & 10.8 \\
\hline $\begin{array}{l}\text { Availability of } \\
\text { antenatal card }\end{array}$ & & & & \\
\hline No & 85 & 61.1 & 59 & 22.7 \\
\hline Yes & 54 & 38.9 & 201 & 77.3 \\
\hline $\begin{array}{l}\text { Number of clini } \\
\text { visits }\end{array}$ & & & & \\
\hline 0 & 83 & 59.7 & 48 & 18.5 \\
\hline $1-3$ & 6 & 4.3 & 10 & 3.8 \\
\hline$\geq 4$ & 50 & 36.0 & 202 & 77.7 \\
\hline $\begin{array}{l}\text { Number of doct } \\
\text { examinations }\end{array}$ & & & & \\
\hline 0 & 87 & 62.6 & 50 & 19.2 \\
\hline $1-3$ & 29 & 20.9 & 32 & 12.3 \\
\hline$\geq 4$ & 23 & 16.5 & 178 & 68.5 \\
\hline $\begin{array}{l}\text { Number of hom } \\
\text { visits by the } P H\end{array}$ & & & & \\
\hline 0 & 100 & 72 & 66 & 25.4 \\
\hline $1-3$ & 32 & 23 & 116 & 44.6 \\
\hline$\geq 4$ & 7 & 5 & 78 & 30 \\
\hline
\end{tabular}

*PHM = public health midwife 
religions were at a high risk for home delivery (Table 2). Mean age of the mothers among the cases was 28.7 years $(\mathrm{SE}=0.5)$, and controls 26.6 years $(\mathrm{SE}=0.3)$. Thirteen mothers $(5 \%)$ of hospital deliveries and five $(3.6 \%)$ mothers of the home deliveries were below the age of 20 years. Almost all the mothers of hospital deliveries were below the age of 39 years. Home delivered mothers had a median of 3 years of schooling and hospital delivered mothers had a median of 9 years. Low educational level (less than 5 years of schooling) of the mother was associated with a 3.5 times increased risk of home delivery (Table 2).

Level of income did not show any significant association with the place of delivery when adjusted for other factors. Type of house (whether permanent structure or temporary building) also did not show any significant association with the place of delivery. Of the home deliveries, $112(80.6 \%)$ families lived in a permanent house.

\section{Parity}

There was a large proportion of women with more than third para among cases (45.3\%) than among controls $(13.5 \%)$ (Table 1$)$. Parity greater than 3 is significantly associated with home delivery (Table 2).

\section{Antenatal care}

Number of examinations by the doctor during the antenatal period and number of home visits by the PHM during the antenatal period were some of the factors significantly associated with home deliveries (Table 3).

Of the hospital deliveries also, 59 (22.7\%) mothers did not have an antenatal card. Of the home deliveries, $83(59.7 \%)$ mothers had never been to a clinic. There were $48(18.5 \%)$ mothers who had not gone to a clinic but delivered in a hospital. Of the home deliveries, $87(62.6 \%)$ women had not been examined by a doctor during the antenatal period. Of the hospital deliveries $50(19.2 \%)$ women had not been examined by a doctor.

Home visiting by the PHM was inversely associated with risk for home delivery. Only 7 (5\%) mothers of home deliveries had been visited by the PHM on more than two occasions. None of the mothers who had delivered at home had been visited by the PHM on more than six occasions.

\section{Selected reason for home delivery}

Lack of transport was the main reason for home delivery as stated by the mothers (Table 4). Of the home delivered mothers, $15(10.9 \%)$ did not like to go to hospital.
Table 2. Association between home deliveries and socio-economic variables

\begin{tabular}{|c|c|c|c|}
\hline Variable & $\begin{array}{l}\text { Crude odds } \\
\text { ratio }\end{array}$ & $\begin{array}{c}\text { Adjusted odds ratio* } \\
\text { (95\% confidence } \\
\text { interval) }\end{array}$ & $P$ value \\
\hline $\begin{array}{l}\text { Ethnicity } \\
\text { Muslim } \\
\text { Non-Muslim }\end{array}$ & 35.7 & $33.0(16.8-64.8)$ & 0.0001 \\
\hline $\begin{array}{l}\text { Maternal age } \\
\geq 35 \text { years } \\
<35 \text { years }\end{array}$ & 2.9 & $1.2(0.5-3.1)$ & 0.63 \\
\hline $\begin{array}{l}\text { Mother's } \\
\text { education } \\
<5 \text { years } \\
\geq 5 \text { years }\end{array}$ & 2.4 & $3.5(1.8-6.6)$ & 0.001 \\
\hline $\begin{array}{l}\text { Parity } \\
\quad>3 \\
1-3\end{array}$ & 5.3 & $3.2(1.5-6.6)$ & 0.002 \\
\hline $\begin{array}{l}\text { Monthly income } \\
\quad<500 \mathrm{Rs} \\
\geq 500 \mathrm{Rs}\end{array}$ & 3.9 & $1.3(0.6-2.7)$ & 0.640 \\
\hline $\begin{array}{l}\text { Ownership of } \\
\text { the house } \\
\text { Own house } \\
\text { Rented house }\end{array}$ & 1.4 & $0.5(0.1-1.6)$ & 0.270 \\
\hline
\end{tabular}

*Adjusted for all other variables mentioned in the table

Table 3. Association between home deliveries and antenatal care

\begin{tabular}{lll}
\hline Variable Crude & $\begin{array}{l}\text { Adjusted* } \\
\text { odds ratio }\end{array}$ & Pvalue \\
\hline
\end{tabular}

Availability of

antenatal card

$\begin{array}{llll}\text { No } & 5.4 & 0.5(0.08-3.0) & 0.456 \\ \text { Yes } & 1.0 & & \end{array}$

Number of

clinic visits

$\begin{array}{llll}0 & 6.9 & 5.2(0.27-97.0) & 0.269 \\ 1-3 & 2.8 & 0.8(0.04-13.6) & \\ \geq 4 & 1.0 & \end{array}$

Number of

examinations doctor

\begin{tabular}{lrll}
0 & 13.5 & $7.0(0.6-83.3)$ & 0.119 \\
$1-3$ & 1.9 & $1.7(0.16-18.8)$ & \\
$\geq 4$ & 1.0 & & \\
Number of home & & & \\
visits by the PHM & & & \\
0 & 16.8 & $2.4(0.8-6.95)$ & 0.119 \\
$1-3$ & 5.4 & $1.2(0.3-5.0)$ & \\
$\geq 4$ & 1.0 & & \\
\hline
\end{tabular}

${ }^{1} \mathrm{PHM}=$ public health midwife

*Adjusted for all other variables mentioned in the table, ethnicity, mothers educational level and parity,

**For each variable the reference category is indicated by crude OR of 1.0 
Table 4. Reason for home delivery as given by the mother

\begin{tabular}{lr}
\hline Reason & Number (\%) \\
\hline Preterm labour & $28(20.3)$ \\
Civil unrest & $15(10.9)$ \\
Lack of transport & $49(35.4)$ \\
Don't like hospital & $15(10.9)$ \\
No one to accompany & $16(11.6)$ \\
Others & $15(10.9)$ \\
Total & $\mathbf{1 3 9 ( 1 0 0 . 0 )}$ \\
\hline
\end{tabular}

\section{Delivery assistant}

Ninety-five percent of the home deliveries were assisted by a traditional birth attendant.

All the hospital deliveries were assisted by trained personnel. Half of the hospital deliveries were assisted by doctors.

\section{Discussion}

Majority of the home deliveries observed were among Muslims (85\%). This was higher than the proportion of Muslims in the study area (52\%). On the other hand, no Buddhist mother had delivered at home.

Low income families were at a higher risk than high income families for home delivery, but this was not significant when adjusted for other factors. Number of home visits by the PHM and number of examinations done by a doctor had influenced the place of delivery, but this is not significant when adjusted for other variables (Table 3). Number of clinic visits varied between 0 and 15 among both cases and controls. There was wide variation in obtaining antenatal care services among the women who lived in the same neighbourhood. Nearly $72 \%$ of the home delivered mothers had not been visited by the PHM during the antenatal period.

The deficiencies in antenatal care increased the risk of home delivery. Poor quality of antenatal care in this area can be explained by several factors. Understaffing of the public health sector was one of the main reasons. Of the 12 PHM positions in the study area, six were vacant during the study period. Apart from this, lack of proper transport and the conflict situation were some of the reasons for poor antenatal care.

The most common reason given for a delivery by mothers who had delivered at home was lack of transport facilities. Of the home delivered mothers, $35.4 \%$ said there was no transport to go to the hospital. There was almost no public transport during the night, and few mothers in this area could afford private transport.

Among the home deliveries, 95\% were attended by a traditional birth attendant. A traditional birth attendant comes from the same socio-cultural background, and was more accepted by the families than a trained midwife.

The present study has some limitations. Only home deliveries that end up in live births were included in the present study, and it did not take into account the outcome of all home births in this area. As a result the number of home deliveries may be an under-estimate of the total.

\section{Conclusion}

A wide range of factors influences the place of delivery in Thampalakamam. The majority of the home deliveries were not planned. Being a Muslim, poor education of women, multiparity, deficiencies in the delivery of antenatal care and lack of transport were found to be important risk factors for home deliveries.

\section{Acknowledgements}

We are grateful to the Deputy Provincial Director of Health Services, Trincomalee, and his staff in helping in data collection.

\section{References}

1. Afsana K, Rashid SF. The challenges of meeting rural Bangladeshi women's needs in delivery care. Reproductive Health Matters 2001; 9: 79-89.

2. Annual Report on Family Health Sri Lanka 2000, Evaluation Unit, Family Health Bureau, Colombo, vol. FH.14.

3. Maternal and Child Health Statistics, Deputy Provincial Director of Health Services' Office, Trincomalee, 2001.

4. Bolam A, Manandhar DS, Shresthe P, Ellis M, Malla K, et al. Factors affecting home deliveries in the Kathmandu valley, Nepal. Health Policy Plan 1998; 13: 1152-8.

5. Carvalho I, Chacham AS, Viana P. Traditional birth attendants and their practices in the State of Pernambulo rural area, Brazil. International Journal of Gynaecology and Obstetrics 1998; 63: 550-3. 